\title{
"FREE TRADE AGREEMENTS - BOON OR BANE?": THROUGH THE LENS OF PACER
}

\author{
Jane Kelsey*
}

This paper examines three dimensions of the Pacific islands' relationship with Australia and New Zealand under the Pacific Agreement on Closer Economic Relations (PACER): first the context, where Pacific governments appear increasingly nervous about free trade negotiations, but believe they have few alternatives; second, how the complex and opaque legal framework of PACER and onerous requirements for WTO compatibility set the terms for future trade negotiations with Australia and New Zealand; and third, the inter-relationship between PACER and the Pacific Plan. It concludes that free trade negotiations risk determining the development options for the Pacific islands and leave no room for Pacific governments or people to explore genuine development alternatives.

\section{INTRODUCTION}

This article examines the question "why free trade agreements?" through the lens of the Pacific islands' relationship with Australia and New Zealand under the Pacific Agreement on Closer Economic Relations (PACER). ${ }^{1}$ It explores three dimensions.

The first of these stresses the importance of context. The Pacific island leaders formally embraced the concept of reciprocal free trade agreements in 1997 in response to changes in their historical relationships and the ascendancy of neoliberal globalisation. Eight years later they are facing an onerous burden of multiple negotiations over which they have relatively little control. A number of governments and their officials are nervous about the implications and defensive in response to pressure on them to proceed at a rapid pace. Yet few believe they have any alternative.

* Professor, School of Law, University of Auckland. This paper was presented at the Australia and New Zealand Society of International Law Annual Symposium "Free Trade Agreements: Boon or Bane for Australasia?" (Victoria University of Wellington, Faculty of Law, 28 August 2005).

1 Pacific Agreement on Closer Economic Relations (18 August 2001), available at Pacific Islands Forum Secretariat (PIFS) <http://www.forumsec.org.fj> (last accessed 18 August 2006) [PACER]. 
The second dimension is the peculiar legal framework of PACER, which sets the terms for future trade negotiations with Australia and New Zealand. These terms are complex and opaque, and the scope and timeframe for negotiations are indeterminate. A legal analysis suggests there is some room for flexibility and sensitivity to the difficult situation facing the Pacific islands. Yet this flexibility is constrained within the trade liberalisation paradigm, the burdensome requirements of World Trade Organization (WTO) compatibility, and the trade negotiating imperatives of Australia and New Zealand.

The third dimension is the inter-relationship between a free trade arrangement under PACER and the emergent Pacific Plan, ${ }^{2}$ of which regional economic integration forms the centrepiece. In October 2005 the Pacific Islands Forum Leaders approved, as part of the Pacific Plan, a proposal to investigate the potential impacts under PACER of a move towards a comprehensive framework for trade (including services) and economic cooperation between Australia, New Zealand and the Forum island countries. This initiative has potentially serious economic, political, development and security ramifications, which the impact assessment seems unlikely to examine.

In closing, this article reflects on the risks that arise when negotiations on trade and economic integration determine the development options for the Pacific islands, rather than being framed by them. It concludes that the pursuit of the current model of regional integration that is driven by economics, formulated by consultants, and fettered by WTO compatibility leaves no room for the governments or people of the Pacific to debate "why not free trade agreements?" and "what else?"

\section{THE CONTEXT}

The Pacific islands face a huge dilemma. The world is changing around them. Yet they remain heavily dependent on former colonial powers, especially Australia, New Zealand, the United Kingdom and the United States of America, for export markets, imports, investment and aid. These economic relationships have been sustained historically through a number of preferential and nonreciprocal agreements that have provided a lifeline for their limited range of commodity exports. By the mid-1990s, with the creation of the WTO and the ascendancy of the neoliberal agenda for globalisation, these arrangements were no longer tenable. This reality was conveyed most starkly in the Green Paper issued in 1996 by the European Union (EU) on future relations with their former African, Caribbean and Pacific (ACP) colonies. ${ }^{3}$ The EU signalled its intention to replace trade preferences under the Lomé Convention with WTO-compatible reciprocal agreements, negotiated

2 PIFS A Pacific Plan: For Strengthening Regional Cooperation and Integration (Final Draft, Suva, 2005) [Pacific Plan], available at PIFS < http://www.forumsec.org.fj> (last accessed 18 August 2006).

3 European Commission Green Paper on Relations between the European Union and the ACP Countries on the Eve of the 21st Century (European Commission, Brussels, 1996). 
on a regional and sub-regional basis. The WTO Dispute Settlement Body (DSB) ruling in 1997 against the EU/ACP banana regime gave impetus to that process. ${ }^{4}$

Economic ministers from the Pacific Islands Forum member countries discussed these developments at their annual meeting in July 1997 and resolved "to pursue a common goal of free and open trade and investment, allowing for the special circumstances of smaller states with few exports". 5 They mandated a study of the options for implementing a free trade area among themselves. Australia and New Zealand, as committed trade liberalisers, were strong advocates of this new agenda. At the inaugural meeting of Forum Trade Ministers in 1998, the Forum's Secretary-General, Noel Levi, endorsed the new trade-led development strategy, more with resignation than enthusiasm. ${ }^{6}$ Levi acknowledged that there was no obvious benefit from freer trade among Pacific islands whose limited trade was in largely similar products, although he noted it was hard to predict what the future might hold. The real objective of the strategy, he conceded, was to create a critical mass, politically and economically, as the Pacific islands engaged with external players: ${ }^{7}$

\footnotetext{
We must prepare ourselves for the changes in global trade now underway. These changes are inevitable as is the need for us to respond or else we get left further behind. We are mostly small and isolated and lack any influence as individual countries. A free trade area creates a larger economic unit or bloc that gives us a stronger foundation for responding to globalisation and universal trade liberalisation ... . Many of the changes have to happen as the world moves towards greater trade liberalisation. This process is not of our making but we cannot sit there and do nothing while the foundations of our economies are being removed.
}

Trade-driven development was, and remains, the centrepiece of the policy advice that the Pacific islands have received from the International Monetary Fund (IMF), World Bank and Asian Development Bank (ADB), ${ }^{8}$ in addition to a series of reports from trade economists that have been commissioned by the Forum Secretariat. ${ }^{9}$

4 United States - European Communities - Regime for the Importation, Sale and Distribution of Bananas (22 May 1997) WT/DS27/R/USA (Panel, WTO).

5 Pacific Islands Forum "Ministers Adopt Action Plan for Sustained Economic Growth in the Pacific" (11 July 1997) Press Release, available at PIFS <http://www.forumsec.org.fj> (last accessed 4 June 2004).

6 Noel Levi Question and Answer Brief on Free Trade Issues (PIFS, Suva, 1999), available at PIFS < http://www.forumsec.org.fj> (last accessed 18 August 2006).

7 Levi, above n 6.

8 See for example Ron Duncan and others Embarking on a Global Voyage: Trade Liberalization and Complementary Reforms in the Pacific (World Bank Report 24417-EAP, Washington, 2002).

9 See generally Robert Scollay Free Trade Options For The Forum Island Countries (PIFS, Suva, 1998) [Free Trade Options]; Robert Scollay and John Gilbert MFN (Non-Preferential) Liberalisation By Forum Island Countries: Commentary On CGE Analysis of Economic Effects (PIFS, Suva, 1998); Andrew Stoeckel 
Many Pacific Islands Forum governments were and remain ambivalent towards the new agenda. In 1998, when they accepted the advice of consultants and formally endorsed the proposal for a Pacific regional free trade agreement, ${ }^{10}$ they originally envisaged a two-stage process. This would begin among them and extend to Australia and New Zealand over a 20 -year period. When told that article XXIV of the General Agreement on Tariffs and Trade (GATT) would require an agreement with Australia and New Zealand to cover "substantially all trade" and be implemented in 10 years, ${ }^{11}$ they sought to retreat to a Pacific island-only agreement. Australia and New Zealand refused to accept that option, especially once the Cotonou Agreement $2000^{12}$ mandated comprehensive negotiations with the EU to be completed by $2007 .{ }^{13}$

The Pacific islands negotiators stood firm against demands for immediate inclusion of Australia and New Zealand. But sustained, and at times unconscionable, pressure eventually resulted in two agreements: the Pacific Island Countries Trade Agreement (PICTA) dealing with trade in goods among the Forum Island Countries (FICs); and PACER, which provides a legal framework for future negotiations of free trade arrangements between the FICs and Australia and New Zealand. These bruising negotiations left a legacy of resentment and distrust that should not be underestimated.

Today, the initial expectation of gradualism has been overtaken by requirements and timelines that are pressing and externally driven. The Pacific islands now risk being submerged in a complex array of WTO-compatible obligations and negotiations:

Costs and Benefits of a Free Trade Area Between Forum Island Countries and Australia and New Zealand (Centre for International Economics, Canberra, 1998); Robert Scollay Impact Assessment of Possible Economic Partnership Agreements (EPAs) with the European Union: A Report for the ACP Secretariat and the Pacific ACP States (PIFS, Suva, 2002); Robert Scollay and Sherry M Stephenson Services Sector Liberalisation for FIC WTO Members: Issues in the Current WTO Negotiations (PIFS, Suva, 2001).

10 Free Trade Options, above n 9, on an agreement among the FICs; Stoeckel, above n 9, advocating inclusion of Australia and New Zealand.

11 General Agreement on Tariffs and Trade (30 October 1947) 55 UNTS 187, art XXIV.

12 Partnership Agreement Between the Members of the African, Caribbean and Pacific Group of States and the European Community and its Members States (23 June 2000) [2000] OJ $317 / 3$ [Cotonou Agreement 2000].

13 Jane Kelsey Big Brothers Behaving Badly: The Implications for the Pacific Islands of the Pacific Agreement on Closer Economic Relations (Interim report, Pacific Network on Globalisation, Suva, 2004) [Kelsey - Big Brothers]. 
- the multifaceted Doha Round of multilateral trade negotiations for current WTO members (Fiji, Papua New Guinea, Solomon Islands and most recently Tonga), ${ }^{14}$ currently scheduled to be completed in $2007 ;^{15}$

- a prolonged WTO accession process involving multilateral and bilateral phases for Vanuatu since 1996 and Samoa since 1998; ${ }^{16}$

- European Commission (EC) negotiations with all fourteen Pacific islands members of the ACP grouping for a regional Economic Partnership Agreement (EPA) pursuant to the Cotonou Agreement 2000, ${ }^{17}$ which are required to be concluded by the end of 2007 for implementation on 1 January $2008 ;^{18}$

- completion of national pre-requisites for signing the revised Melanesian Spearhead Group (MSG) Preferential Trade Agreement in goods between Vanuatu, Papua New Guinea, Fiji and Solomon Islands, and establishment of the MSG Secretariat in Vanuatu, ${ }^{19}$

- imminent implementation of PICTA, including domestic legislation to amend tariff schedules, its proposed expansion to include the United States Compact States (Palau, the Marshall Islands and the Federated States of Micronesia) and possibly the French Pacific territories, and agreement "in principle" to its extension to cover services;

- an obligation to consult with a view to negotiations for a regional economic integration arrangement with Australia and New Zealand under PACER, at the latest in 2011 or earlier if triggered by negotiations with the EU or other developed states, ${ }^{20}$ and

- the anticipated revision of Compacts of Free Association with the United States for the Federated States of Micronesia, the Marshall Islands and Palau.

14 Tonga's Protocol of Accession was signed at the WTO Ministerial Conference in Hong Kong in December 2005 , and was expected to be ratified by the Government of Tonga by 31 July 2006; however, ratification was deferred in July 2006 for one year.

15 For a detailed discussion of issues arising from the WTO Doha round and WTO accessions see Jane Kelsey "World Trade and Small Nations in the South Pacific Region" (2005) XIV(II) Kan J L \& Pub Pol'y 247.

16 In relation to Vanuatu, see also Roman Grynberg and others "The Accession of Vanuatu to the WTO: Lessons for the Multilateral Trading System" (2000) 34(6) JWT 159.

17 Cotonou Agreement 2000, above n 12, pt 3, tit II, ch 1, art 34

18 For a discussion of these negotiations, see Jane Kelsey A People's Guide to the Pacific's Economic Partnership Agreement. Negotiations between the Pacific Islands and the European Union pursuant to the Cotonou Agreement 2000 (World Council of Churches Office in the Pacific, Suva, 2005).

19 "Sir Allan Speaks Highly of Melanesian Spearhead Group" (22 August 2005) Port Vila Presse Vanuatu.

20 See Jane Kelsey A People's Guide to PACER. The Implications for the Pacific Islands of the Pacific Agreement on Closer Economic Relations (Pacific Network on Globalisation, Suva, 2004). 
Alongside all these is the development of the Pacific Plan.

It is timely to recall that some Pacific islands have only one or two people to cover all these negotiations, many of whom have limited experience or expertise. This is compounded by a high turnover of personnel. Even Fiji has lacked a trade lawyer on its negotiating team. Moves to improve capacity at the national level through technical assistance pose problems of externally generated perspectives and priorities, especially as EC funding has been directed at strengthening the Forum Secretariat at the expense of individual Pacific islands governments. ${ }^{21}$

\section{THE LEGAL FRAMEWORK OF PACER}

Given the dominant economic role of Australia and New Zealand in South Pacific trade and aid, and their political role through membership of the Pacific Islands Forum, it was inevitable that the implementation of PACER and the development of the Pacific Plan would loom large in this crowded programme.

Both are intended to build on PICTA, which provides for the liberalisation of trade in goods amongst its developing country parties (Fiji, Tonga, the Cook Islands and Papua New Guinea) within eight years and ten years for the remaining Small Island States and Least Developed Countries (LDCs). A further four years is allowed for sensitive products. ${ }^{22}$ Surprisingly, this timeline was modelled on article XXIV of the GATT, which applies to regional trade agreements where developed countries are parties, apparently on advice from the WTO Secretariat to the Forum's consultants. This is despite the fact that more flexible arrangements were available to the Pacific islands under the Enabling Clause, ${ }^{23}$ and that only six of the fourteen negotiating parties to PICTA were Members of the WTO or in the process of accession.

As of April 2006, all FICs except Tuvalu and the Compact States had acceded to PICTA. ${ }^{24}$ Trading under PICTA was scheduled to begin in 2006. However, progress towards the

21 Kelsey, above n 18, 53

22 Alcohol and tobacco were initially excluded for three years, pending examination of the implications of their inclusion. That was extended in 2005 for a further two years following several reports from Fijian economist Wadan Narsey. See Wadan Narsey "PICTA, PACER and EPAs: Odd Detours in PIC Development" (paper presented to "Beyond MIRAB: The Political Economy of Small Islands in the $21^{\text {st }}$ Century", Victoria University of Wellington, February 2004); and Wadan Narsey Trade Liberalisation and Fiscal Reform. Towards a Negotiating Framework for Economic Partnership Agreements with the European Union (Pacific Institute of Advanced Studies in Development and Governance, Suva, 2004) [Narsey - Fiscal Reform].

23 WTO Differential and More Favourable Treatment. Reciprocity and Fuller Participation of Developing Countries (Enabling Clause) (L/4903, Geneva, 1979) [Differential and More Favourable Treatment].

24 Vanuatu only completed its accession to PICTA in 2005. The Compact States were given three years' grace to consider the implications for their relationship with the United States, which requires MFN treatment for any such arrangements, and none has yet made any moves to accede. New Caledonia has indicated a desire 
implementation of the pre-requisite changes to legislation was slow, ${ }^{25}$ and reflected similar difficulties in relation to the Melanesian Spearhead Group. ${ }^{26}$ While there is provision under article 19 PICTA for extending the scope of PICTA, and that was agreed in principle for services in $2003,{ }^{27}$ this process also appeared to be moving slowly.

PICTA was portrayed as a "stepping stone" that would lay the economic and political foundations for the renegotiation of the Pacific islands' preferential trade arrangements with the EU, as required by the Cotonou Agreement 2000, and with Australia and New Zealand as mandated by PACER.

PACER is formally described as the "umbrella" agreement under which PICTA sits, although few of the Forum Islands governments appear to see it that way. ${ }^{28}$ Given the fraught negotiating history of PACER, it is not surprising that the legal text is complex and opaque. On one hand, this could provide flexibility for the Pacific islands as they grapple with their goal to integrate into the global economy; on the other hand, it may be interpreted in ways that severely constrain their available options. Five legal questions are examined here: the scope of a future arrangement between Australia and New Zealand and the Pacific islands; the implications of WTO compatibility for a region where the majority of states are not WTO Members; the conditions for triggering negotiations earlier than 2011; the timeline for concluding such a free trade arrangement; and the provision of trade facilitation, technical assistance and related support.

\section{A Scope of a Future Legal Arrangement}

The first issue is the scope of any future legal arrangements that result from PACER. This is especially pertinent given the very broad scope of the EPA negotiations with the EU. The range of terminology used in PACER makes this hard to discern.

The preamble talks of "encouraging trade liberalisation and economic integration ... with a view to the eventual full and complete integration of all sectors of [the parties'] economies". Article

to join PICTA. See PICTA status report as at February 2006, available at PIFS $<$ http://www. forumsec.org $>$ (last accessed 18 August 2006).

25 "Implement Reforms or Suffer More Pain, Forum Warns Island Countries" (June 2005) Islands Business Suva.

26 T K Jayaraman "Regional Integration in the Pacific" (Working Paper, University of the South Pacific, Suva, 2005/6) 12.

27 This intention was reiterated in the Kalibobo Road Map annexed to the Communique of the 36th Meeting of the Pacific Islands Forum (Madang, Papua New Guinea, 25-27 October 2005): see Ministry of Foreign Affairs and Trade < http://www.mfat.govt.nz> (last accessed 18 August 2006).

28 Kelsey, above n 20, 16. Tuvalu, Vanuatu and The Marshall Islands, who were signatories to PACER, have not ratified the agreement: see PACER status report as at February 2006, available at PIFS < http://www.forumsec.org> (last accessed 18 August 2006). 
2 on "Objectives" in part 1 on "Definitions and Objectives" refers to PACER "establishing a framework for the gradual trade and economic integration of the economies of the Forum members" (emphasis added). Among the listed objectives in article 2 are (a) "to provide a framework for cooperation leading over time to the development of a single regional market" and (b) "to foster increased economic opportunities and competitiveness through more effective regional trade arrangements" (emphasis added).

These phrases imply regional integration arrangements that extend beyond trade to the entire economies of all parties to PACER. So does the heading of part 2: "Pacific Economic Integration Initiatives". Within that part, article 3 on "Guiding Principles" emphasises trade, but not exclusively. Article 3(2) refers to trade arrangements that provide stepping stones to gradual participation in a single regional market. Article 3(3) says the purpose of free trade areas is to facilitate trade and not to raise external barriers to trade. However, article 3(1) describes PACER as establishing a trade and economic partnership and article 3(4) explicitly preserves the right of parties to undertake arrangements outside PACER to regulate trade and economic relations. Article 4, dealing with arrangements among the FICs, states the desirability of beginning with trade liberalisation and economic integration among themselves first. It also records the potential to adopt a different pace and priorities when they liberalise trade and integrate their economies with Australia and New Zealand.

Yet the operative provisions in part 2 focus narrowly on trade in goods. The nub of PACER is found in article 5 on "Future Negotiation of Forum-wide Trade Arrangements". Article 5(1) contains an obligation to "enter into negotiations with a view to establishing reciprocal free trade arrangements between the Forum Island Countries and Australia and New Zealand" (emphasis added). It provides three pathways to these negotiations. First, negotiations must begin eight years after PICTA came into effect (in April 2003, meaning negotiations in April 2011). Second, they can be triggered earlier under the complex provisions of article 6 by negotiations between a Party to PACER and one or more non-Forum parties. Third, they can be agreed to through the three-yearly review of PACER conducted under article 16(2).

Separately from this, article 5(2) provides the possibility for any one party to PACER to seek consultations with a view to creating, extending or deepening trading and economic integration arrangements between all the FICs and Australia and New Zealand. Presumably, the distinct reference to reciprocal free trade arrangements in article 5(1) and trading and economic integration arrangements in article 5(2) was deliberate. On its face, this suggests that moves towards broader economic integration arrangements under article 5(2) are subject to consultation and consensus, whereas negotiations on a narrower reciprocal free trade arrangement are (ultimately) mandatory under article 5(1).

What, then, might be covered by "reciprocal free trade arrangements" under article 5(1)? For the purposes of article 5, that term is not defined. The only definition of "free trade arrangements" provided in PACER is found in article 6, and means "at least one free trade area or customs union, 
or at least one agreement leading to the formation of such an area or union, as defined in article XXIV.8 of the General Agreement on Tariffs and Trade" (emphasis added). This limits the scope of such an arrangement to trade in goods, with no obligation to include services, investment, intellectual property, competition, government procurement or any other "trade-related" topic. That definition exists expressly for the purpose of article 6, which relates to only one of the three pathways to negotiations for a "free trade arrangement" under article 5 - that being the triggering of early negotiations before 2011 .

This reading seems counter-intuitive. The definition in article 6 has two applications: to the kind of negotiations that might be triggered through this pathway and to the kind of negotiations that might trigger them. Taking the former, it seems incongruous to suggest that the negotiations for free trade arrangements that may be triggered early under article 6 should differ substantially from those that would otherwise arise in 2011. Applying this narrower meaning to all the article 5(1) pathways, rather than just one, would be consistent with the contrasting broader reference to "trading and economic integration" arrangements in article 5(2).

Moreover, this narrow interpretation appears to contradict the reason why Australia and New Zealand insisted on having the article 6 triggers: to ensure that they were not disadvantaged within the Pacific region by agreements that the FICs negotiated with non-Forum countries - in particular, the Economic Partnership Agreements with the EU. As the scope of the EPA provided for in the Cotonou Agreement 2000 extends beyond goods, one would expect a comparably broad definition of free trade arrangements to include at least the services equivalent of article XXIV of GATT, being article V of the General Agreement on Trade in Services (GATS) ${ }^{29}$ Moreover, the current practice of Australia and New Zealand in negotiating free trade arrangements extends well beyond trade in goods. Australia's Free Trade Agreements (FTAs) with Singapore, the United States and Thailand and their negotiations with China cover a WTO-plus range of goods, agriculture, services, investment and government procurement. ${ }^{30}$ New Zealand employs a combination of Closer Economic Partnerships (with Singapore, later extended to include Chile and Brunei and renamed the TransPacific Strategic Economic Partnership Agreement, and Thailand) and negotiations for Free Trade Agreements (with the Association of Southeast Asian Nations (ASEAN), China and Malaysia). Both are broadly similar in scope to Australia's FTAs. ${ }^{31}$

As a secondary consideration, article 6(6) PACER was also meant to provide assurances to the Pacific islands parties that they could seek improved market access arrangements where new FTAs

29 General Agreement on Trade in Services (15 April 1994) 1869 UNTS 183, art V.

30 See Australian Government, Department of Foreign Afffairs and Trade $<$ http://www.dfat.gov.au/trade $>$ (last accessed 18 August 2006).

31 For an index of these arrangements see Ministry of Foreign Affairs and Trade <http://www.mfat.govt.nz $>$ (last accessed 18 August 2006). 
entered into by Australia and New Zealand placed them at a disadvantage. If free trade arrangements are limited to trade in goods, where the Pacific islands already enjoy duty free access, it is difficult to see what this might mean, other than altering the Rules of Origin in ways that could restore some lost competitive advantage and market share. However, if a broader interpretation was adopted this could, for example, open the way for negotiations on market access for services.

One explanation for the limiting scope in article 6 might be the undue burden of broader based negotiations at such an early stage; yet there is no in-built provision to revisit the scope of such an agreement in 2011. Because PICTA was limited to trade in goods it may also have been politically difficult for Australia and New Zealand to secure a broader definition. Whatever the reason, and however counter-intuitive it might seem, the narrow definition in article 6(1)(a) must be read as deliberate and determinative.

This seeming anomaly has become tactically important. The strategy developed by the Pacific ACP countries for their negotiations with the EU seeks to avoid an agreement on trade in goods and hence the triggering of negotiations with Australia and New Zealand. ${ }^{32}$ As of April 2006 it appears that the EC may accept a multilateral approach to an agreement on trade in goods and a Pacific ACP agreement relating to services and investment. However the EPA text is framed, Australia and New Zealand could be expected to seek a comparable agreement on services and investment to any that was signed with the EU. Yet there seems to be no legal basis on which they could require that under article 6. They would need to fall back on the other pathways in article 5: through the inbuilt negotiations in 2011; by agreement during a scheduled three yearly review of PACER under article 16(2); or following an open-ended request for consultations under article 5(2).

Defining the scope of these other pathways is also complicated. As discussed earlier, it is logically difficult to justify a definition of "free trade arrangements" in article 5(1) that differs from that in article 6 and is comparable to that in article 5(2), but legally there is scope to do so. The review provision in article 16 supports this. Article 16(1) requires annual reviews of the implementation and operation of PACER and "all aspects of trade and economic cooperation between the parties" (emphasis added). Article 16(2) mandates a general review of the "operation of the agreement" no later than three years after PACER came into force - meaning 2005 - and triennially thereafter.

The purpose of both kinds of review according to article 16(3)(a) is to "make decisions, as required, on the opening and timetabling of negotiations for agreements or arrangements to provide for the broadening and deepening of the economic integration of the Parties, and to monitor those negotiations" (emphasis added); and under article 16(3)(b) to "reach agreement on actions necessary

32 See Kelsey, above n 18, 48-49. There are also concerns about the implications of article XXIV GATT requirements on "substantially all trade", given the predominance of sugar and canned fish in the Pacific ACP's exports to the EU. 
to harmonise and coordinate the trade and economic integration arrangements of the Parties" (emphasis added). Further, the affirmation in article 3(7) that PACER does not require notification under article $\mathrm{V}$ of the GATS may imply that arrangements reached pursuant to PACER are expected to include commitments on trade in services.

Indeed, article 16(2) seemed to be the path adopted by the Forum Trade Ministers at their annual meeting in May 2005, when they called for an impact assessment of negotiations under PACER to be prepared for their annual meeting in 2006. ${ }^{33}$ This suited both the Pacific islands, who want flexibility to avoid an article XXIV GATT-style agreement on trade in goods (for reasons explained below), and Australia and New Zealand who want broader ranging negotiations than are mandated by the article 6 definition of free trade arrangements. These divergent objectives seemed destined to ensure that progress, if any, would be slow. The terms of reference were still not agreed, let alone the study conducted, when the Trade Ministers met in May 2006.

\section{B WTO Compatibility}

Given these uncertainties and ongoing tensions, it is essential to establish the degree of flexibility that is available to PACER parties. Again, the drafting is messy.

All members of the WTO are required to comply with the rules of the GATT and the GATS on regional trade agreements relating to their scope, implementation periods and notification. PACER itself was designed not to be a regional trade agreement, and therefore not to require notification to the WTO. That was explicitly affirmed in article 3(7). Both the Preamble and the objectives in article 2(2)(e) aim to achieve consistency with any party's WTO obligations. Article 5(1) on future negotiations of "free trade arrangements" refers back to the objectives; indeed, article 6(1)(a) defines "free trade arrangements" with reference to article XXIV:8 of the GATT. Although the wording in article 6(7) only requires the parties to endeavour to negotiate arrangements that are consistent with the relevant provisions of all the WTO agreements, any agreements on goods or services that involve WTO members are ipso facto subject to its rules.

These WTO-linked obligations raise some fundamental development concerns. Of the FICs only Fiji, Papua New Guinea and Solomon Islands are currently WTO Members. Vanuatu completed the process in 2001 but deferred indefinitely the signing of the Protocol of Accession. Tonga signed its Protocol of Accession in December 2005, with ratification scheduled for July 2006; this was delayed at the last minute in response to mounting domestic disquiet. Samoa is actively engaged in a prolonged process of accession. A majority of the FICs are not WTO members and are never likely to join. Yet the requirement of WTO compliance extends to them all.

33 This was confirmed in the Communique of the Forum Leaders Meeting in October 2005. The Minutes of the Trade Ministers Meeting are not publicly available. 
Secondly, all FICs are developing countries. A majority of them fall into the categories of Small Vulnerable Economies, Small Island States and/or LDCs. The Preamble to PACER and article 2 on "Objectives" make specific reference to their different levels of economic development and special vulnerability, and the need to minimise the disruptive effects and adjustment costs of trade liberalisation and economic integration. The "Guiding Principles" in article 3 say that LDCs and Small Island States may be integrated through different structures and timeframes. Parties also promise to use "best endeavours to follow international best practice in formulating the rules governing the trade relations between them, taking into account the development status, capacity and resource constraints of Forum Island Countries". ${ }^{34}$ Article 4 reiterates differentials of pace and priorities for all the FICs relative to Australia and New Zealand. Article 7 says any new trade arrangements must be consistent with all the above, recognise differences in development status by "appropriate" measures for special and differential treatment for developing countries, and not discriminate between the Pacific islands, except for special and differential treatment of LDCs and Small Island States.

According to the preamble and article 2(2)(e), PACER should be consistent with the Parties' obligations under the WTO. That includes the special and differential treatment for developing countries and concessions to LDCs contained in the WTO texts, such as access of developing countries to the Enabling Clause that provides less onerous obligations for regional trade agreements among themselves. ${ }^{35}$ Equally, the article 12 commitment in PACER to mutual assistance in the WTO on matters related to its terms and obligations, recognising the development levels and vulnerabilities of the Pacific islands, should extend to negotiations under the Doha Declaration and Working Programme: notably paragraphs 12 on "Implementation-related Issues and Concerns", 35 on "Small Economies", 38 to 41 on "Technical Cooperation and Capacity Building", 42 and 43 on LDCs, and 44 on "Special and Differential Treatment". 36

However, there is well-grounded scepticism about the New Zealand and Australian governments' commitment to this aspect of article 12 and the special development position of the Pacific islands. There is little in their track record during the Doha Round to show more than

34 Which institutions' approaches might be considered "best practice" is likely to be a matter of dispute if Australia and New Zealand draw on APEC and the Pacific Islands seek to rely on the United Nations Conference on Trade and Development (UNCTAD) or the United Nations Development Programme (UNDP)

35 Differential and More Favourable Treatment, above $\mathrm{n} 23$.

36 WTO Doha Ministerial Declaration (WT/MIN(01)/DEC/1, 2001). 
lukewarm support, and sometimes opposition, to many of the positions argued by the Small Vulnerable Economies, the ACP Group, the Group of 90 and the LDCs. ${ }^{37}$

This is compounded by their self-serving behaviour towards the Pacific islands engaged in accession, especially their failure to give good faith effect to the December 2002 decision of the WTO General Council on accession of LDCs, as reiterated in paragraph 42 of the Doha Work Programme, that "WTO Members shall exercise restraint in seeking concessions and commitments on trade in goods and services from acceding LDCs, taking into account the levels of concessions and commitments undertaken by existing WTO LDC Members". ${ }^{38}$ Vanuatu and Samoa, as LDCs, are entitled to the benefit of that decision. Both governments have been critical of Australia and New Zealand's aggressive pursuit of precedents and their strategic trade objectives; ${ }^{39}$ one Samoan official has publicly accused New Zealand of failing to give effect to the 2002 General Council Decision. $^{40}$

The third major development issue involves article XXIV of the GATT. The PACER text abounds with promises of sensitivity and flexibility and constantly emphasises a "gradual" and "progressive" process resulting in "eventual" integration in the global economy. Yet the WTO requires all regional trade agreements that involve developed countries (in the case of PACER, Australia and New Zealand) to cover "substantially all trade" and be implemented, except in exceptional circumstances, within a period of 10 years. ${ }^{41}$ There is no special provision in the GATT for regional trade agreements between developed and developing or LDCs (let alone those who are not WTO Members at all), although there is some more recognition in the counterpart article V of the GATS. ${ }^{42}$

37 For example, there are very few references to interventions by Australia and New Zealand in the records of the Work Programme on Small Economies in the Committee on Trade and Development, and those tend to be ambivalent.

38 WTO Accession of Least Developed Countries (WT/L/508, Geneva, 2003).

39 For its own description of its approach, see Australian Government, Department of Foreign Affairs and Trade "WTO Accessions and How Australia Stands to Benefit" < http://www.dfat.gov.au> (last accessed 18 August 2006) (making no reference to LDCs). See also Australian Government, Department of Foreign Affairs and Trade "The Government's Key Market Access Wins for Agri-Food (Mid 1996 - 25 February 2000)" <http://www.dfat.gov.au> (last accessed 18 August 2006).

40 See Kelsey - Big Brothers, above n 13, 247.

41 See "Understanding on the Interpretation of Article XXIV of GATT 1994" in WTO The Legal Texts: The Results of the Uruguay Round of Multilateral Trade Negotiations (Cambridge University Press, Cambridge, 1999) 26.

42 This requires "substantial sectoral coverage" and non-discriminatory "national treatment" in a "reasonable" timeframe, but allows more flexibility where developing countries are parties and especially where they are the only parties. 
These obligations are the subject of paragraph 29 of the Doha Work Programme on Rules, which mandates "negotiations aimed at clarifying and improving disciplines and procedures under the existing WTO provisions applying to regional trade agreements. The negotiations shall take into account the developmental aspects of regional trade agreements." 43 The Pacific islands WTO members, as part of the ACP, have urged formal recognition of special and differential treatment under article XXIV GATT for agreements between developed and developing countries. ${ }^{44}$ They note the de facto flexibility that arises from the vagueness of the terms "substantially all trade" and "reasonable length of time", but the lack of de jure protection if this is tested through the Dispute Settlement Mechanism. The ACP proposed, amongst other things, the formal inclusion of special and differential treatment for developing countries in paragraphs 5 to 8 of article XXIV GATT; flexibility in the methodology and threshold levels for determining "substantially all trade" and "other restrictive regulations of commerce"; and a transition period for developing countries of not less than 18 years. ${ }^{45}$

As previously noted, article 12 of PACER imposes obligations of mutual assistance in the WTO, with special reference to development. Yet there is no evidence of support for the ACP position from Australia and New Zealand. Their only formal submission, in June 2003, related to transparency. ${ }^{46}$ Australia has taken a particularly hard-line approach to the interpretation of article XXIV GATT - a position that may be undermined by the 18 year transition it has allowed the United States in relation to dairy and beef products in the Australia United States Free Trade Agreement 2004. ${ }^{47}$

There is little likelihood that the negotiations on rules in the Doha Round will produce anything beyond some greater transparency in regional trade agreements or that the concerns about developed/developing country trade agreements will be addressed. That leaves the Pacific islands in an invidious position in negotiating a free trade arrangement on goods, whether under article 5 or article 6 of PACER. ${ }^{48}$

43 Doha Ministerial Declaration, above n 36.

44 WTO Submission on Regional Trade Agreements: ACP Group of States (TN/RL/W/155, Geneva, 2004) [ACP Submission].

45 ACP Submission, above n 44.

46 WTO Submission on Regional Trade Agreements: Australia, Chile, Hong Kong, China, Korea and New Zealand (TN/RL/W/117, Geneva, 2003).

47 Australia - United States Free Trade Agreement (18 May 2004) [2005] ATS 1, annex 2-B.

48 Similar concerns arise more urgently for the Pacific islands from requirements of WTO compatibility in the Cotonou Agreement 2000. The concentration of sugar and canned fish exports to the EU leaves Pacific ACP countries with no real flexibility, whether "substantially all trade" is defined by tariff lines, trade volume or asymmetrically. The EC has made limited gestures to acknowledge the problem facing ACP countries, 


\section{PACER's Triggers}

The most threatening and urgent concern for the FICs has been the potential to trigger negotiations under article 6 . The configurations by which this can occur are truly Byzantine.

First, under article 6(3)(a), if any single FIC party to PACER begins formal negotiations for free trade arrangements with a developed country other than Australia and New Zealand it is obliged to "offer to undertake consultations as soon as practicable with Australia and New Zealand, individually or jointly, with a view to the commencement of negotiation of free trade arrangements" (emphasis added).

Secondly, under article 6(3)(b), if a FIC party has concluded negotiations with any nondeveloped country it must offer to undertake consultations as soon as practicable. These consultations have no stated objective. Whilst it might be inferred that the purpose is the same as article 6(3)(a), this is not explicit. According to the same clause, where those negotiations are concluded with a non-developed country whose GDP is higher than New Zealand's (such as Singapore) that consultation must be followed by offering the opportunity for negotiation of free trade arrangements, which begs the purpose of the consultation.

To reiterate an earlier point, these obligations to Australia and New Zealand only arise when a FIC negotiates for an article XXIV GATT-style agreement on trade in goods. Their nature is vague and indeterminate: the consultations do not have to begin until "practicable", there is no timeframe for the commencement of negotiations, nor any requirement that an agreement is concluded. They are activated when negotiations have formally begun or been concluded. The obligations are graduated according to whether the other party is a developed, non-developed or richer developing country, reflecting the degree of perceived threat to Australian and New Zealand economic and strategic interests.

Viewed another way, any FIC that is party to PACER can avoid this trigger by not entering negotiations with a non-FIC party or by negotiating with a poor country; by ensuring that any negotiations they do enter into are not for an article XXIV GATT-style agreement on trade in goods; by ensuring that if they do formally begin such negotiations with a developed country, that they do not end up agreeing to an article XXIV GATT-style agreement; by asserting that their lack of capacity makes consultations impracticable; or by ensuring that they enter in good faith into indeterminate negotiations with Australia and/or New Zealand.

Article 6(4) provides a further convoluted trigger. When all parties to PICTA jointly begin negotiations for free trade arrangements (as defined in GATT article XXIV) that would include one or more non-Forum country they must offer to undertake consultations as soon as practicable with

falling well short of the development rhetoric and promises of mutual assistance in the WTO provided in the Cotonou Agreement 2000. 
Australia and New Zealand, individually or jointly, with a view to the commencement of negotiation of free trade arrangements.

This is subtly different from article 6(3). For reasons that are unclear, it omits the word "formally" before the commencement of negotiations. The same outcome applies to negotiations with any non-Forum party, whatever their development status. Yet it only applies where all parties to PICTA commence those negotiations and do so jointly. If only one party to PICTA does not participate, or several groups of FIC enter separate negotiations, this trigger can be avoided.

There is a further provision under article 6(6) whereby formal negotiations between Australia or New Zealand and a non-Forum country for a (article XXIV GATT) free trade arrangement can activate a trigger. This requires Australia or New Zealand to offer to undertake consultations with individual FIC governments with a view to negotiating better market access, an offer that the island government can accept or refuse. ${ }^{49}$

Finally, there is potential for any PACER party to request consultations where it believes an expected benefit has been nullified or impaired. This applies to benefits under part 2 on "Economic Integration Initiatives" and part 3 on "Trade Facilitation and Economic and Technical Assistance".

These complex configurations spurred Pacific islands governments to adopt a defensive strategy in their negotiations with the EC to avoid or delay triggering negotiations with Australia and New Zealand. First, the launch of "formal" negotiations was deferred until 2006, with the EC's concurrence. Second, the talks would focus first on services and investment. ${ }^{50}$ Third, any negotiations on trade in goods would be multilateral and sectoral, thus avoiding an article XXIV GATT-style agreement. A fall-back option exists, if that strategy fails, whereby the developing countries could opt for the EC's revised General System of Preferences (GSP) or the GSP-plus, ${ }^{51}$ and the LDCs could rely on the Everything But Arms arrangement. ${ }^{52}$ Even if these triggers were

49 It appears that there have been discussions about the impact on the Pacific islands of free trade agreements entered into by Australia and New Zealand in areas such as the export of tropical fruits. However, given the existing duty free entry for Pacific island exports, it is unclear what market access remedies might be available here; assistance with trade facilitation and quarantine requirements would seem more relevant.

50 PIFS The Pacific ACP EU Partnership. The Way Forward (Suva, 2004). The EC agreed in June 2005 to an initial focus on investment, tourism and fisheries: "EPA Negotiations Begin in Suva Tomorrow" (28 July 2005) Pacific Magazine Honolulu; "Pacific Islands Win Agreement from EU" (28 July 2005) Radio Australia Australia.

51 European Commission "GSP: The New EU Preferential Terms of Trade for Developing Countries" (MEMO/05/43, Brussels, 2005).

52 This special category of the GSP provides duty free, quota free entry for almost all goods from LDCs; see Gateway to the European Union "General Systems of Preferences: Legislation, Reports and Texts" < http://europa.eu.int> (last accessed 18 August 2006). 
avoided, however, the obligations under article 5(1) of PACER to begin consultations in 2011 would still remain.

\section{Timelines}

Irrespective of when negotiations begin, there are issues of timelines. Like the Cotonou Agreement 2000, PACER provides a framework for future negotiations. The former has a deadline of December 2007 in relation to goods, which is when the WTO waiver for existing EU/ACP preferences expires. ${ }^{53}$ There is no similar deadline for the more ambiguous expectations of negotiations on services, investment, competition and more.

By contrast, PACER sets no deadline for completing any negotiations. Under article 5(3) existing market access preferences will continue until new or improved arrangements that provide equal or better access for the FIC have been concluded. ${ }^{54}$ Article 7 affirms that the terms of any new trade arrangements must provide FIC parties with no less favourable treatment than exists under article 5(3). This guarantee has its limitations, as the value of existing terms of access will continue to be eroded through unilateral and bilateral liberalisation by Australia and New Zealand and any results from the Doha Round. The current special SPARTECA-TCF arrangement on garments also expires in 2011. ${ }^{55}$ Nevertheless, as the Pacific islands are aware, there is potential to drag out negotiations under article 5(1) for a very long time, should they wish to do so.

\section{E Support Obligations}

Part 3 of PACER on "Trade Facilitation and Economic and Technical Assistance" has distinct but related provisions on trade facilitation and financial and technical assistance. These are conceptually linked to part 2, but broader in scope. The preamble and the article 2(c) "Objective" aim to "minimise any disruptive effects and adjustment costs ... including through assistance and support ... to undertake the necessary structural and economic adjustment for integration". Article 9 requires the establishment of detailed programmes for the development and implementation of trade facilitation measures to enhance trade liberalisation. These are expected to complement other

53 WTO European Communities - the ACP-EC Partnership Agreement (Ministerial Decision) (WT/MIN(01)/15, Geneva, 2001). This does not apply to sugar, which is governed by a legally separate protocol, but is also caught up in the wake of a WTO dispute.

54 These preferences are mainly through the South Pacific Regional Trade and Economic Co-operation Agreement (SPARTECA), but there are also bilateral arrangements, such as the Papua New GuineaAustralia Trade and Commercial Relations Agreement (PATCRA II).

55 A new iteration of the SPARTECA (TCF Provisions) Scheme under the South Pacific Regional Trade and Economic Co-operation Agreement was negotiated between Australia and Fiji in 2004 and provides duty relief on imports of TCF goods under complex Rules of Origin. See SPARTECA (TCF Provisions) Scheme, available at Department of Foreign Affairs and Trade, Australia "Republic of the Fiji Islands Country Brief - July 2006" <http://www.dfat.gov.au> (last accessed 18 August 2006). 
requirements and international trade facilitation initiatives, and their design and allocation of funding is to be sensitive to the development status of the LDCs and Small Island States.

Article 11 likewise makes provision for financial and technical assistance not only for trade facilitation and promotion and capacity building, but also for structural adjustment, including fiscal reform. This too is to be set out in a work programme, to be administered within the Forum Secretariat and supported "with an adequate level of funding" from Australia, New Zealand and other interested donors.

The allocation of funding for the Regional Trade Facilitation Programme was the first aspect of PACER to become operational. It was an inauspicious beginning. The decision of Australia and New Zealand to fund only half of what the Pacific islands originally asked for, and that further funding should be sought from other sources, provoked a standoff. Some governments saw it as further evidence of bad faith by Australia and New Zealand and manipulation of the rules to suit their interests and reinforce their power. The deadlock was broken by Fiji (a major potential beneficiary), which argued that the offer was realistic given the Pacific islands' capacity to use the funding, so long as they could seek further allocations when that was exhausted. ${ }^{56}$

Again, PACER differs from the Cotonou Agreement 2000, where the inter-relationship of aid, finance, political relationships and trade is made explicit. Article 6(12) of PACER specifically delinks trade negotiations from the provision of aid or technical assistance, aside from the specific provision of support for trade facilitation, adjustment and technical assistance. Even assuming the legal position under PACER is reflected in practice - and informal communications suggest there have been threats to those governments who are not playing the game ${ }^{57}$ - Pacific islands governments will be tempted to see trade negotiations as a trade-off for more cash in their governments' coffers.

\section{THE PACIFIC PLAN FOR REGIONAL INTEGRATION}

Much has changed since PACER was signed off in 2002. The pace of bilateral negotiations involving Australia and New Zealand intensified as the Doha Round became bogged down. Strategic discussions among the Pacific islands about their approach to negotiations with the EC increased their knowledge and understanding of the process and rules, and helped to identify the priorities they wish to pursue. New Zealand and Australia seem less obsessed about protecting their competitive advantage in the Pacific from the Europeans. After being called to account publicly for their self-interested bullying of the Pacific islands, New Zealand officials at least claim there is a

56 Similar issues have arisen in the Cotonou negotiations, where a smaller than expected allocation of funding from the EC has required a revision of negotiating priorities by the Pacific ACP grouping.

57 This observation is based on discussions between the author and senior officials from a Pacific Islands government. 
new attitude to trade negotiations. "Civil society" in the Pacific has also become more informed and assertive of its right to voice concerns about the trade liberalisation agenda.

These shifts are coinciding with the development of the Pacific Plan, a process initiated by New Zealand when it chaired the Forum in 2004. An Eminent Persons Group report was followed by a reflection group on that report and a task force of officials from the Pacific islands produced a document for consultation. ${ }^{58}$ The blandness of that document suggested a reluctance to advance the process very far or very fast. The ADB funded a consultation process and a series of consultants' reports that were commissioned by the Forum Secretariat, ${ }^{59}$ with support from the Commonwealth Secretariat. In October 2005 the Forum Leaders endorsed the Pacific Plan at their annual meeting in Papua New Guinea.

The evolving regional strategy is built around four pillars: economic growth, sustainable development, good governance, and security. But, as the June 2005 meeting of Forum Economic Ministers made clear, stronger regional economic integration, starting with trade, would be a central element of the Pacific Plan. ${ }^{60}$ This needs to be understood in light of the previous discussion: regional economic integration will have to take a WTO-compatible form, which means a development model that is premised on globalised markets and structured according to rules that are designed by and for the world's major powers.

\section{A Economic Growth}

It is an article of faith, spelt out in the preamble to PACER, that trade liberalisation and economic integration will benefit the economies of the Pacific islands. Indeed, PACER's framework, backed by requirements of WTO compatibility, allows no other pathway. The promise of benefits to the Pacific islands from a "trade-driven development strategy" and economic integration has been constantly reinforced by economic consultancy reports that are commissioned by the Forum. These routinely rely on easily manipulated econometric modelling and questionable assumptions, and treat neo-classical economic theory as incontestable. ${ }^{61}$

The Declarations from ministerial meetings of the Forum endorse this position and political leaders add their imprimatur. According to Fiji's Trade Minister, Kaliopate Tavola, in August 2005, "expanding the purely trade agreement into a developmental tool in the same mould as the

58 Pacific Plan, above n 2.

59 For example, Asian Development Bank Technical Assistance for Developing and Implementing the Pacific Plan for Strengthening Regional Cooperation and Integration (Financed by the Japan Special Fund) (TAR OTH 38615, Manila, 2005).

60 Forum Economic Ministers Meeting "Joint Media Statement" (9 June 2005) Press Release, available at PIFS < http://www.forumsec.org.fj> (last accessed 18 August 2006)

61 Joseph Stiglitz Making Free Trade Work for All: How Trade Can Promote Development (Oxford University Press, Oxford, 2005) ch 2. 
Economic Partnership Agreement (EPA) of the Cotonou Agreement [2000], is seen as a means of widening the benefits that will accrue to Fiji and to the rest of the Pacific Island countries". 62

Yet Pacific island governments also have their reservations, as evidenced by public criticism of the WTO from Fijian Ministers; ${ }^{63}$ Vanuatu's ongoing resistance to completing its WTO accession on terms dictated by the United States, and its decision not to join PACER; ${ }^{64}$ a Samoan negotiator's criticism of the New Zealand government's demands during its accession; ${ }^{65}$ the defensive strategy adopted by the Pacific ACP group in negotiations with the EC to avoid PACER; ${ }^{66}$ the "trade war" between Vanuatu and Fiji over biscuits and kava; ${ }^{67}$ and more.

Such examples could be dismissed as classic by-products of the "political economy of change". An empirical assessment of the impact of Vanuatu's Comprehensive Reform Programme, including unilateral trade liberalisation and WTO accession, offers a different insight. Vanuatu's former economic adviser, Daniel Gay, argues that small vulnerable countries must maintain policy space and genuine flexibility in developing their economic strategies. ${ }^{68}$ Some factors affecting the Pacific islands, such as propensity to natural disasters and remoteness, are fixed. But it is not inevitable that these countries must rely on a small number of low value-added agricultural commodities whose prices fluctuate widely, even if this is theoretically their comparative advantage. Achieving greater diversification requires long-term programmes that are designed to boost export-oriented sectors, provide access to credit for local entrepreneurs and develop potential in services like tourism. The protection that is necessary to encourage local producers and domestic competition is often incompatible with external liberalisation. Insisting on trade liberalisation can also have the perverse

62 "Fiji Can Play Leadership Role In PICTA and PACER - Tavola" (8 August 2005) Press Release, available at Fiji Government $<$ http://www.fiji.gov.fj $>$ (last accessed 18 August 2006).

63 "The WTO claims to be a multilateral trading organisation which addresses the circumstances of all its Members, and whose rules provide a balance of advantages for all its constituents. However, this is unfortunately not true for the small, vulnerable economies ...": Hon Kaliopate Tavola, Fiji Minister of Trade Statement on Behalf of Small Vulnerable Economies to Fifth Session of WTO Ministerial Conference (WT/MIN(03)/ST/87, Geneva, 12 September 2003).

64 Roy Mickey Joy, Chief Trade Policy Advisor to Vanuatu Government Presentation to the INCD Panel (WTO Public Symposium, Geneva, April 2005).

65 Interview with Tuala Falani Chan Tung (Sunline, April 2004). A copy is on file with the author.

66 Summarised in PIFS, above $\mathrm{n} 50$.

67 "Vanuatu; Turning the Tide Against Free Trade: Protectionism Leads to Ban on Fiji Biscuits" (July 2005) Islands Business Suva; "Fiji, Vanuatu Representatives Pledge to Resolve Trade Bans" (22 August 2005) ABC Radio Australia Australia.

68 Daniel Gay "The Emperor's Tailor: An Assessment of Vanuatu's Comprehensive Reform Programme" (2004) 19(3) Pacific Economic Bulletin. 
result of promoting exploitive private sector monopolies in very small markets, notably in services such as telecommunications or water.

Even within the trade liberalisation paradigm, economic studies highlight issues of concern. It is paradoxical that the legal ambiguities in articles 5 and 6 of PACER could create space for the Pacific islands to avoid negotiating with Australia and New Zealand on non-goods areas, such as services and investment, at least until after 2011. Yet it is an agreement on goods that may prove most problematic for the Pacific islands in terms of revenue, production, imports and jobs. ${ }^{69}$

Work by Wadan Narsey on the economic implications of including alcohol and tobacco in PICTA raises wider questions about the redistributive effects of regional economic integration among the Pacific islands, and subsequently with Australia and New Zealand. ${ }^{70}$ Alcohol and tobacco are important sources of production and employment for many islands and a vital source of tariff revenue for all. For example, at the time of his study British American Tobacco owned all tobacco production in the Pacific islands. The factories in Solomon Islands, Papua New Guinea and Samoa relied on imported inputs and would not satisfy the Rules of Origin under PICTA. Because Fiji used locally grown tobacco, the company was likely to shift to Fiji and operate a regional monopoly from there. But those gains would be short-term. If the free trade area was extended to Australia and New Zealand, the company was likely to exit Fiji and export to the Pacific islands from its plants in Australia, New Zealand or both.

Narsey suggested that similar effects could be expected for most manufacturing. Gains to some islands under PICTA would mean closure of businesses and loss of jobs in others. Their governments were likely to react in a knee-jerk manner and pull back - as occurred with Solomon Islands, Vanuatu and Fiji in the Melanesian Spearhead Group. Producers who benefited under PICTA, especially in Fiji, were likely to find these gains disappear under PACER as investors relocated to Australia and New Zealand and serviced the region from there. If those firms had become even more important to Fiji's economy and employment, that government would face greater pressure to protect them and prevent closures or relocations. Such moves could conflict with the rules on free trade in goods (and in services and investment) in such an arrangement. Moves to enforce those rules would increase domestic tensions within Fiji, with ripple effects across the region.

This led Narsey to question whether the Pacific island governments should be encouraging the expansion of firms to take advantage of PICTA when they would not survive the loss of preferences. His proposal to move directly to negotiations with Australia and New Zealand for a

69 This is not to ignore the serious issues raised by agreements on services, investment and government procurement, among others.

70 Discussed in Narsey - Fiscal Reform, above n 22. 
flexible free trade arrangement assumed more legal space and political will than this article's analysis of PACER suggests would be available.

There are also major revenue impacts for the Pacific islands through reductions to tariffs, which provide between one fifth and almost half of their government revenue. In 2004, Narsey argued that tariff loss to the Pacific islands from extending to Australia and New Zealand any free trade commitments they made to the Europeans had been underestimated. ${ }^{71}$ The kind of goods imported from Australia and New Zealand tended to attract higher tariffs, so the loss would be higher. Moreover, goods that appeared to be Fijian exports were often re-exports of goods imported from Australia and New Zealand. That meant they would not satisfy the Rules of Origin in either PICTA or PACER, but would be defined as Australian or New Zealand goods instead. In considering various configurations, including use of excise taxes on "sin" goods, such as alcohol and tobacco, VAT and income tax (for Vanuatu), Narsey stressed the need to assess the consequences of their application not only to the EU, but also to Australia and New Zealand.

There are counter-arguments that fears of fiscal impacts ignore the level of avoidance that currently exists and that replacement by consumption taxes can improve transparency and the efficiency of tax collection. On the other hand, the redistribution of the tax burden from tariffs on luxury items to a levy on essentials is especially significant in subsistence economies. If tariff cuts do not flow onto prices, consumers pay more for imported products too. ${ }^{72}$ These impacts can provoke demands for wage increases and political unrest. The Tongan government's drastic cuts to its tariffs and Port and Services Tax, as required by its WTO accession commitments, and introduction of a consumption tax were major contributors to the union-led upheaval in 2005.

In times of economic crisis, the ability to resort to tariffs is an essential lifeline. When shortfalls in government revenue increase pressure for cuts to government expenditure, the economic, social and political ramifications can be severe. Too little attention has been paid to these real life impacts of trade liberalisation in the Pacific context, and there was no sign that they would form part of the terms of reference for the proposed "impact assessment" of PACER.

\section{B Sustainable Development}

References to sustainable development and poverty elimination occur only in PACER's preamble ("Confirming their commitment to sustainable development and the elimination of poverty in the region") and article 3 on "Guiding Principles" ("The objectives of sustainable development ... and gradual and progressive integration ... into the international economy shall guide all aspects of all stages of the development of the trade and economic partnership ..."). It is simply assumed that

71 Narsey-Fiscal Reform, above n 22.

72 Working Party on the Accession of the Kingdom of Tonga Draft Report of the Working Party on the Accession of the Kingdom of Tonga (WT/ACC/SPEC/TON/4/Rev 2, Nuku'alofo, 4 May 2004); Oxfam Blood From a Stone (Oxfam International Briefing Paper, Oxford, 2005) 5. 
trade liberalisation and economic integration will help engender sustainable development and eliminate poverty. This resolves any tension between Australian and New Zealand self-interest and the development needs of the Pacific islands.

Challenges to this trade-driven development model come from a diversity of commentators, whose proposals range from reforms that appeal to the beneficence of richer and more powerful countries, to opposition to neo-liberal globalisation as irreconcilable with people-centred development. ${ }^{73}$ There was no room for any such debate before PACER was signed. Despite frequent calls from Pacific non-governmental organisations (NGOs) since the late 1990s, Forum member governments and the Forum Secretariat refused to conduct any genuine development impact assessments to evaluate their claims. ${ }^{74}$ Whether this refusal was driven by ideology, political arrogance or a lack of confidence in what such studies might show is immaterial.

The only "social impact assessment" commissioned to date was commissioned by the Forum Secretariat on PICTA in 2001. ${ }^{75}$ The consultants argued that PICTA would not have much economic impact, so its social effects would also be negligible. To the extent that there would be impacts, economic theory told them that PICTA would produce lower unemployment, rising incomes, better living standards and improve the status of women. As if to confirm the tokenism of the study, the Forum Trade Ministers noted the report at the same meeting as they signed both PICTA and PACER. They asked the Forum Secretariat to convene a regional workshop on training and preparations to establish a framework to monitor PICTA, without any resources to do so.

Three years later the Secretariat finally contracted two regional women's organisations - the Pacific Foundation for the Advancement of Women (PACFAW) and the United Nations Development Fund for Women (UNIFEM) - to work alongside it to provide national level social impact assessment training. This training was to help national officials to implement a module that had been prepared by an outside consultant. One stated goal of the training was to convince participants of the value of social impact assessments. The first such assessment would not be conducted until at least 2006 and would be solely about PICTA.

73 See, for example, Stiglitz, above n 61; Civil Society Forum Declaration to UNCTAD XI (TD/407, 12 June 2004, Brazil); Deepak Nayar Trade and Development. Some Reflections on the Linkages (Third World Network, Penang, 2006), available at <http://www.twnside.org.sg > (last accessed 18 August 2006); Walden Bello "What's Wrong with the Oxfam Campaign?" (2002) 77 Focus on Trade.

74 A recent example was a statement from Fiji Civil Society in September 2004: "We express disappointment that no comprehensive people-centred social impact studies have been done on the sectors that may be addressed in the EPA negotiations. Government must not enter into any EPA commitments until it has examined the economic, social, environmental and gender impacts of existing free trade commitments." See Pacific Islands Association of NGOs < http://www.piango.org > (last accessed 18 August 2006).

75 David Forsyth and Ni-K Plange "Social Impact Assessment of Membership of the Pacific Free Trade Area" (University of the South Pacific, Suva, 2001). 
The first formal pre-Forum meeting of "civil society organisations" in Apia in 2004 pleaded for a moratorium pending an open-ended assessment of PACER's implications: ${ }^{76}$

The Forum Leaders are urged to use the development of the Pacific Plan to generate a broad ranging national and regional debate with the full participation of civil society on the kind of economic development models the peoples of the Pacific want. The debate should include the exploration, recognition, support and protection for indigenous economic and development models. Pacific Forum Countries should work together to sustain ably and equitably manage the fisheries resources of the Pacific. We recommend that the PICTA/PACER three-year review be deferred until there is a full, participatory and transparent assessment of their actual and potential impacts of member countries and local communities ....

A proper development impact assessment would involve empirical analysis at national levels, with participation of communities in identifying benefits, problems and alternatives, supported by a commitment of time, resources and political will. The Forum Trade Ministers meeting in May 2005 decided to use the three year review of PACER to conduct a rather different joint study on the potential impact of a region-wide economic partnership agreement to be negotiated under PACER, and a "gap" analysis of Pacific islands governments' needs in respect of capacity building, trade promotion and structural reform. ${ }^{77}$ New Zealand officials initially expected the study to focus on structural impacts and economic reform and to be in draft form when the Forum Leaders met in October 2005. Later there were suggestions of disagreement between the two governments, with New Zealand saying there needed to be an element of social impact assessment. By April 2006, behind the scenes negotiations between Australia, New Zealand and the Forum Secretariat had eventually produced a set of draft terms of reference that were sent to the Pacific islands governments, who demonstrated their opinion by a culturally familiar silence.

\section{Good Governance}

The Pacific Plan sets a single strategic objective for "good governance": "[i]mproved transparency, accountability, equity and efficiency in the management and use of resources in the Pacific." ${ }^{78}$ This classic neo-liberal prescription for a managerial state belies the serious political and constitutional issues that regional integration through PACER will pose for governance in the Pacific.

76 "Apia Statement 2004: Recommendations on the Five Thematic Areas Discussed During the 5th Civil Society Forum" Pacific Islands Association of NGOs <http://www.piango.org $>$ (last accessed 18 August 2005).

77 "Pacific Island Nations Seek Closer Economic Partnership with New Zealand and Australia" (30 May 2005) PACNEWS Fiji; Forum Trade Ministers Meeting Outcomes Document ((05) FTMM, PIFS, Nadi (Fiji), 27 May 2005).

78 Forum Trade Ministers Meeting, above n 77, para II.4.12. 
These issues arise at four levels: the nature of the "partnership" between Australia and New Zealand and the FICs; legitimation problems for regional decision making mechanisms; conflicts with national sovereignty and constitutionality; and the deficit of democratic participation in decision making at national and regional levels.

The term "partnership" is a modern euphemism for longstanding political and economic relationships of inequality and dependency. Economic Partnership Agreements are used to designate the new reciprocal trading relations between the ACP sub-regions and the EU whose terms, timelines and processes are dictated by the former colonial powers. The same imbalance pervades the notion of a partnership with Australia and New Zealand. Australian Prime Minister John Howard justified the creation of a Pacific Economic Community in July 2003, saying: "Many of these countries are too small to be viable ... and we really have to develop an approach that I could loosely call pooled regional governance...". ${ }^{79}$ Pacific islands governments should be prepared to endorse such a proposal "especially because we provide a lot of aid". ${ }^{80}$ The Strategic Assessment for 2002 by the Australian Strategic Policy Institute, funded by the Australian Defence Department, spelt this out more bluntly: ${ }^{81}$

For many decades we sought to protect Australia's interests by supporting colonial rule in one form or another .... Australian policy since decolonisation has consistently stressed the need to allow these countries to manage their own problems .... It seems that as far as our Melanesian relationships are concerns, this approach will no longer work.

The New Zealand government may seek to distance itself from such statements, but Australia's attitude is likely to have a determinative influence on the shape of any integration within the region - unless the FICs and New Zealand become extremely assertive, in which case Australia may threaten to disengage. The New Zealand government is unlikely to risk a further distancing of the Trans-Tasman relationship. If Australia does dictate the terms, old forms of resistance to colonialism can be expected to re-emerge.

There is an air of unreality when academics and policy makers talk about regional governance, and the potential to replicate the ACP/EU Parliamentary Assembly or even the EU itself in the South Pacific region. This assumes a high level of political coherence across the Pacific islands that ignores cross-cutting divisions between Melanesian and Polynesian, and small and larger islands, let alone with Australia and New Zealand. Disagreement and fracture at all those levels has been

79 Quoted in Iggy Kim "Howard's Pacific Colonialism: Who Benefits?" (20 August 2003) Green Left Weekly Australia.

80 Quoted in Kim, above n 79.

81 Australian Strategic Policy Institute Strategic Assessment 2002 (Canberra, 2002). 
evident, for example, in recent appointments of the Forum Secretary-General and the ACP Secretary-General. ${ }^{82}$

Institutionalisation of regional decision-making would presumably centre on the Pacific Islands Forum. The recent battle over leadership of the Forum has undermined the sense of ownership among many of the Pacific islands. EC insistence that funding to support the EPA negotiations must be directed to the Forum as the regional integration organisation has fuelled fears of empire building. The Forum's role in coordinating the Pacific Plan has also fostered a sense of disempowerment among some governments and many civil society organisations, especially when terms of reference for the impact assessment have been pre-cooked with Australia and New Zealand.

Regional decision-making requires legitimacy. There is no mandate for the transfer of sovereign authority to a regional entity. It is true that no Pacific island state exercises sovereignty in its fullest political, economic and legal sense. At the same time, the sovereign independence of many Pacific islands was hard-won by their people. It is not for transitory elected governments, acting as the executive, to sign this away through secretive negotiations. Indeed, in a number of Pacific islands any such transfer of political authority would require formal constitutional amendments. ${ }^{83}$

This tension is highly sensitive and often denied. In late 2005 the Forum's Secretary-General, Greg Urwin, insisted that: ${ }^{84}$

The Pacific Plan is not intended to replace national policies, but to support and complement them ... . Protecting and enhancing national sovereignty is, in fact, a key goal of regionalism. ... Governments can, in fact, enhance their sovereignty by allowing regional bodies to implement some of their policy decisions (in effect, as service providers). This devolution of service provision to regional mechanisms may allow national governments to focus on critical priorities ....

This contrasts with a speech in 2004 by Isikeli Mataitoga, the Chief Executive of Fiji's Ministry of Foreign Affairs and External Trade and chair of the Pacific ACP negotiating group with the EC: $: 85$

82 "PM's Man Wins Forum Top Job" (17 August 2003) The Age Melbourne; "Decision Time - Tuilaepa, Sir Michael Meet and it Will be Pacific Way" (7 August 2004) Samoa Observer Online $<$ http://www.samoaobserver.ws> (last accessed 18 August 2006).

83 This point is made in relation to Fiji by Isikeli Mataitoga in the Foreign Affairs Bulletin (Ministry of Foreign Affairs and External Trade, Government of Fiji, Suva, 2004).

84 Greg Urwin "Regionalism and the Pacific Plan" (International Labour Organisation Public Lecture, Suva, 15 November 2005).

85 Mataitoga, above n 83. 
Fiji's constitution recognizes that in areas of law making, the Fiji Parliament is supreme in that regard. It's the Fiji Parliament only that is empowered to make laws for the good order of the land and its people. It is also true generally and especially in the area of trade policy formulations and regulations that agendas are set in accordance with the dictates of the Bretton Woods Institutions [World Bank, ADB, WTO etc]. The domestic law making that follows that agenda setting are more in the nature of rubber stamping rather than a critical evaluation of what is best for the country.

He went on to ask how the government can better project its own development priorities in the environment of trade negotiations: "The principles of the separation of powers of State and the supremacy of Parliament within that is under threat. How do we engage this change while remaining true to these cardinal principles of our constitution?" 86 These are fundamental questions of governance. These are more than mere problems of "political economy of change" to be circumvented by binding treaty obligations. They are a recipe for national and regional instability.

Negotiations for regional economic integration with Australia and New Zealand would reshape economic and social life in the Pacific islands and close off the policy space available to governments to pursue any model for development other than WTO-compatible globalisation. As the EC remarked in its 1996 Green Paper on future relations with ACP countries, "[t]he future partnership will fit into a long transition process which will transform not only the economic organization of the country, but also society itself." ${ }^{17}$ Few in government or business understand where this transformation could lead, let alone the citizens whose lives will be turned upside down.

Gay has observed how imposing an external agenda can backfire: "[e]ven if the [Comprehensive Reform] programme had been technically successful there is a moral angle too - a critical mass of country inhabitants must own a reform package rather than having it foisted upon them." 88 A policy template that is driven by theory, has been devised from outside, ignores the realities of the country, and is implemented at a culturally alien speed is bound to be sabotaged and fail. Governments become paralysed and the costs are then borne by their people. This helps explain why the Vanuatu Government decided not to accede to PACER. ${ }^{89}$

The deepest irony in the good governance rhetoric is that negotiations for "free trade arrangements" that are conducted by the executive under conditions of secrecy are profoundly antidemocratic. The process strengthens the power of unaccountable governments and can increase, rather than constrain, opportunities for corruption. Citizens are disenfranchised, in the name of liberating consumers. It is disappointing, but not surprising, that political leaders endorse this

86 Mataitoga, above n 83.

87 European Commission, above n 3, 12, ch III.

88 Gay, above n 68, 17.

89 This does not preclude their participation in negotiations for a free trade arrangement under article 6. 
agenda at meetings of Forum Ministers, often despite their reservations, and remain reluctant to expose their negotiating positions to prior scrutiny. This is not simply because it would undermine their bargaining position or because they lack the resources to engage in a public debate. It is also because many are unwilling to have their previous decisions criticised and enjoy the opportunity to exercise executive power free from democratic oversight.

\section{Security}

Increasingly, the designation of Pacific islands as "failed states" because of internal conflict, corruption or intrinsic lack of capacity is cited as the justification for external intervention. While military intervention is recognised as invasive and seen to require an invitation, economic intervention tends to be portrayed as an apolitical means of ensuring that governments adopt objectively "sound" policies. Yet many of the policies that governments are required to implement, whether by IMF conditionalities, World Bank and ADB "Poverty Reduction Strategy Programmes" or free trade obligations, are deeply de-stabilising. Governments may refuse to, or only partially, implement them because they will cause major unrest. Such reluctance or inertia is often taken as justification for requiring governments to move further and faster through binding and enforceable free trade and economic integration agreements. ${ }^{90}$

Even advocates of trade liberalisation concede that forcing the Pacific islands down such a path "for their own good" may have serious economic, social and political implications, albeit for the short term. The new director of trade policy at the Commonwealth Secretariat, Roman Grynberg, has previously stressed the risk of inappropriate trade liberalisation for the Pacific islands and questioned whether they are stable or strong enough to weather the severe political and economic consequences of the very long and difficult transitions that these policies would require. ${ }^{91}$ It will be interesting to see how those risks are integrated into the future negotiation of WTO-compatible agreements under his watch.

\section{CONCLUSION}

The notion of a free trade and economic integration agreement between the FICs, Australia and New Zealand is deeply problematic. The Pacific islands are engaged in a game of Russian roulette. There are serious risks of significant economic, social and political upheaval. Yet no social or development impact assessments have been conducted. "Civil society" in the Pacific islands has objected that neither it nor its governments properly understand the implications. Despite the public façade, the Pacific islands governments do not have a common vision of their way forward

90 This view was explicitly expressed by Duncan and others, above n 8, 23.

91 Roman Grynberg The Pacific Island States and the WTO; Towards a Post Seattle Agenda for the Small Vulnerable States (PIFS, Suva). 
collectively, and many are hostile to a more powerful role for the Forum Secretariat. In a region where instability is already an issue, this seems a reckless path to be travelling at such speed.

Even the advocates of a free trade agreement under PACER must recognise that proposals for imminent negotiations are highly premature. For PACER's critics, the problem lies with the model itself, which risks fuelling an implosion that will further de-stabilise an already fragile region. A genuinely participatory Pacific Plan that has ownership of both the governments and the people of the Pacific islands would require an exploration of all the options. This includes a constructive and forward-looking debate that is free to ask: "why not a free trade agreement with Australia and New Zealand?" and "what alternative development strategies might better serve the Pacific islands, individually and collectively, in the future?" 
